\title{
Africa-China Cooperation:
} Potential Shared Interests and Strategic Partnerships?

\author{
Abdoulkadre Ado, University of Ottawa, Canada \\ Ellis L.C. Osabutey, University of Roehampton, UK
}

\section{Introduction}

Burgeoning Africa-China trade has reached a new high of more than $\$ 100$ billion in 2017 . Over the last decade, Chinese investments and financing in Africa have exceeded $\$ 300$ billion, and China now holds $\$ 110$ billion of FDI stock in Africa. Notwithstanding continuing trade with traditional Western partners, China is now Africa's leading trade partner, with continuously increasing trade volumes. Figure 1 shows that exports from Africa to China surpassed $\$ 380$ billion between 2010 and 2016. This outstripped African exports to France and Spain combined. The figures are even higher for imports from China to Africa, which reached over $\$ 445$ billion during that same period; more than the continent imported from US and France combined. This demonstrates a clear shift in Africa's trade pattern.

Figure 1. Africa's Major Trade Partners

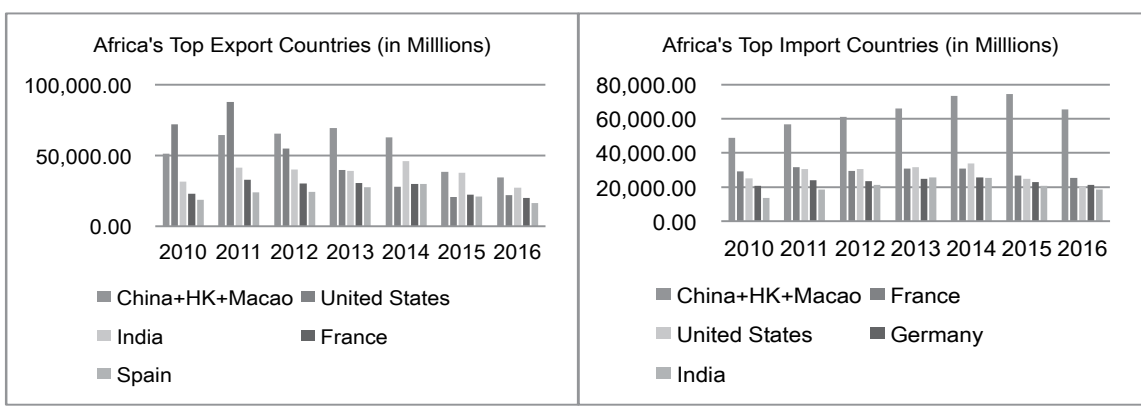

Source: Adapted from IMF data warehouse

There is emerging debate on the long- and short-term potential gains or losses for Africa. Is this rapprochement a strategic one? Some analysts credit China with promoting the strong economic growth of some African countries, while others blame
China for crashing local African businesses. There are calls for a more win-win relationship through the identification of potential congruent policymaking and development agendas.

\section{Potentiall of Congruent Agendas and Policies}

Africa has increasingly turned toward China for funding of development projects in recent years, making the Dragon the new top financier of Africa's construction sector, according to a Deloitte's 2017 report. Arguably, new aspirations expressed in Agenda 2063 to develop and industrialize Africa in the next five decades or earlier (African Union, 2018) can have inextricable links with China's recent Belt and Road Initiative (BRI) towards increasing Chinese globalization. These two major visions (Africa's Agenda 2063 and China's BRI) require mutually beneficial cooperation.

The Forum on Africa-China Cooperation (FOCAC) can serve as an institutional bridge toward achieving Africa's priority goals (value chain upgrade, integration and infrastructure, and knowledge gain) and development vision alongside strategically positioning China into the global economy. This requires government policies, especially on the African side, that are aligned with the dynamics of the tripod (Bridge - Goals - Vision). Deliberate and well-regulated policies can help attract more relevant Chinese investments, which would support Africa in its quest for Chinese technology and knowledge. Such an integrated and 
symbiotic developmental relationship would engender an impetus for a more significant participation of China and Africa in the global value chain. Since the benefits to Africa of Africa-China relations are often subject to scholarly debate, this paper offers insights from a multifaceted perspective. Figure 2 presents the framework of our analysis. import of cheap Chinese products could annihilate some of the continent's infant industries (Zhao, 2014). However, African countries generally need to catch up technologically (Osabutey, Williams \& Debrah, 2014) and could acquire new technologies and capabilities via Chinese engagement for meaningful integration into the global value chain.
Figure 2. Bridging Institutions, Goals, and Visions
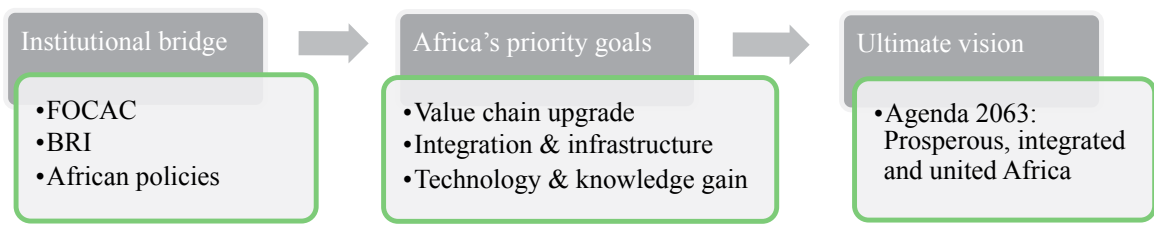

Figure 2 shows how we conceptualize African development through the Agenda 2063 lens. Africa can achieve its development objectives if it capitalizes on its cooperation with China while developing policies that utilize FOCAC and BRI as bridging institutions. In addition, financing from China would help reduce Africa's reliance on Western and multilateral traditional financiers. China can, therefore, support African integration, infrastructure development, and knowledge transfer toward the continent's better positioning in the global value chain.

In the following sections, we present some insights on how Chinese investments can augment African efforts in developing more value-adding activities. Second, we discuss how FOCAC and BRI, as institutional bridges, can contribute to Africa's Agenda 2063 regarding infrastructure development and integration. Third, we evaluate how the Africa-China relationship can serve as a conduit for technology and knowledge gain. Finally, we conclude and synthesize related implications.

\section{Africa's Global Value Chain Up- grade: Role of Chinese Investments}

While China's share of global manufacturing of value-added activities as well as related wages have been on the rise, there is an increasing interest in supporting Africa to develop (or relocate) a manufacturing base. Some Chinese companies have already moved lower-value manufacturing facilities to Africa. African companies can take advantage of this development to tap into global value chains. A growing number of Chinese entrepreneurs are setting up processing and production facilities to add value to raw materials in Africa. Some Chinese manufacturers are also taking advantage of emerging opportunities such as the African Growth Opportunity Act, which give African-based firms preferential access to markets in the US. Inadvertently, China is bringing Africa in the global value chain by outsourcing much of its lower-end production. Some African businesses fear such competition in production and the
Policymaking in Africa should monitor China's low value-added and non-environmentally friendly activities. African countries should avoid previous experiences with former colonial and Western multinationals which invested in offshore business activities, such as dirty mining, that were considered unacceptable in their home countries. Thus, Africa needs to prioritize investments that tie in with its long-term prosperity. To ensure a win-win symbiotic cooperation, Africa needs to evaluate and learn from previous experiences with the global West to guide its increasing engagement with China (Ado \& Su, 2016). African countries need to, individually or collectively, prioritize Chinese investments that are impactful in upgrading economic activities into the global value chain.

Africa needs to look for foreign technologies to upgrade their competitiveness in the global value chain (Osabutey et al., 2014). There are potential cultural and institutional synergies between China and Africa to facilitate South-South technology and knowledge transfers. (Ado, Su, \& Wanjiru, 2017). Existing evidence is mixed, and the Chinese presence has not sufficiently transferred significant technology or built much local capacity in Africa (Elu \& Price, 2010). Related training courses for African officials (Tugendhat \& Alemu, 2016) and demonstration centres (Xu et al., 2016) are often fragmented and lack proactive initiatives from Africans to upgrade priority sectors (Ado et al., 2017).

\section{African Integration and Infrastructure Development: Role of FOCAC and BRI}

A major aspiration of Agenda 2063, as stated by the African Union (AU), is to establish a united, prosperous, and integrated continent based on the ideals of Pan Africanism (African Union, 2018). The initiatives include (a) Continental Free Trade Area (CFTA), (b) Integrated High Speed Train Network, (c) African Commodity Strategy, and (d) Continental Financial Institutions. FOCAC, since its inauguration in 2000 with three-year African engagement plans, is well-placed to support and coordinate Chinese investments to achieve these initiatives. At the recent FOCAC meeting, China extended $\$ 60$ billion of financing and investments to Africa for the next three years. The Chinese President intimated that a significant portion of this commitment will primarily go to Africa's infrastructure 
development (Xinhua, 2018). African governments should therefore take advantage of this opportunity to channel the funds towards Agenda 2063, which prioritizes infrastructure development (roads, railways, airports, etc.) towards regional integration and geographical connectivity.

FOCAC has the advantage of providing a multilateral engagement framework and can provide a platform for a bargaining power for both Africa and China vis-à-vis the West and other nations. FOCAC has played a significant role in strengthening economic interests between China and Africa and engineered humanitarian benefits to Africa. Since the formation of FOCAC, China waived billions of dollars of debt to many African countries and trained thousands of Africans across various sectors (Ado et al., 2017). There have also been zero tariff rates for hundreds of products from Africa. In addition, China is involved in peace-keeping operations on the continent. Moreover, President Xi announced, at the 2018 FOCAC, that China is exempting several African countries from their debt (Xinhua, 2018). Therefore, FOCAC is instrumental in enhancing gains from the relationship but requires good negotiation skills and strong strategic thinking from the African side.

Africa can increase benefits by encouraging Chinese investments that support Agenda 2063. For instance, China has one of the most efficient high-speed trains in the world and should thus be considered by Africans as a strategic source of finance and expertise for specific AU flagship projects. Such strategic collaborations can deliver efficient and pragmatic project outcomes with requisite technology and knowledge transfers for future projects as well as repair and maintenance.

China's new BRI can also be a conduit for achieving Agenda 2063 particularly with respect to Africa's vision for infrastructure development. Since Africa is expected to play an important role in BRI (Kodzi, 2018), aligning infrastructure needs with achieving CFTA within China's BRI framework is key. The BRI can further internationalize Chinese companies as well as increase global economic and political influence. Meanwhile, the framing of the BRI gives Africa unprecedented opportunities to negotiate for more inward Chinese FDI. Roads, railways (Integrated High-Speed Train Network), airlines, and maritime infrastructures are some of the most significant opportunities for Africa with regards to China's BRI. Examples of BRI's significant spillovers include ongoing construction of a major port and mall in Djibouti. This means Chinese FDI in BRI constitutes a good avenue for boosting African economic integration. In addition, aligning BRI with CFTA would reduce transportation costs to improve continental trade.

Since the BRI aims at forging win-win cooperation that supports development and prosperity through investment and trade, a strategic and well negotiated CFTA and BRI through FOCAC can integrate investment and development in Africa. To achieve these objectives, Africa needs to reduce related
Sino-African power asymmetry (Kodzi, 2018) through a new approach to policymaking. Africans need to understand the dynamics of how foreign investments can interact with development programs. This would help to evaluate the suitability of Chinese investments.

Africans cannot assume that they need Chinese investments in every sector of their economies. Since China is currently classified as a developing country, it too exhibits weaknesses in some sectors. For instance, Africa can evaluate if it needs to look elsewhere or within itself for investments in education infrastructure. Meanwhile, it should prioritize technology and knowledge transfer, necessary for global value chain upgrade, by learning from China's recent development history and experiences.

\section{Africa-China Relationship as Conduit for Technology and Knowledge Transfer}

Most of the emerging scholarly debate appears not to adequately look beyond historical relations between Africa and the Global North (Lumumba-Kasongo, 2011) to explore potential benefits of Africa-China cooperation and how that could accentuate African development. Mohan and Lampert (2013) observe that most analyses of China's recent engagement with Africa portray China as the dominant force, with Africa simply being a passive receiver of Chinese investments with a relatively insignificant power to impose conditions. They note that such studies tend to focus on Chinese and African state actors and political relationships (Carmody \& Kragelund, 2016). While this dependence has the potential to support African economic growth, Kaplinsky and Morris (2009) argue that countries in Africa require deliberate strategies and policies that can enhance potential gains and limit negative effects. They argue that current aid, trade, and policy frameworks appear to be one-sided and do not necessarily serve Africa's best interests. A more proactive policymaking and engagement is therefore required from the African side. African countries ought to be able to mobilize strategies that integrate trade, aid, financing, and development (Carmody \& Kragelund, 2016) so that Chinese investments and related technology and knowledge transfer can contribute to upgrading firms from Africa into the global value chain.

The impact of increasing Chinese investments varies across African countries. In some cases, investments are timely and significantly support many underperforming sectors. Other investments have also opened the door for African infant industries to access technology and knowledge. Indeed, the case of the Lekki Free Zone Development Company (LFZDC) illustrates how some Nigerian partners have taken advantage of China's presence in Africa (Ado et al., 2017). LFZDC is 
attracting new Chinese investors in Lagos but also enabling the relocation of segments of the value chain to Nigeria. Indeed, finished goods that used to be imported from China, such as Chinese trucks, are now being assembled in Lagos. Chinese investments can therefore be channeled towards strategic and symbiotic technology and knowledge transfers.

\section{Conclusion and Implications}

The international business and related literature is beginning to explore the nuances of Africa-China relations. However, some analysists are often overly simplistic: Can we say that everything that China is doing in Africa is great? Certainly not. Can we say that China's presence in Africa is entirely bad? Certainly not either. The reality is that the relationship is developing in such a way that both parties, at least at the governmental levels, appear comfortable. Is this direction sustainable and strategically beneficial for both parties from a rational analysis? The answer will vary across countries. One of the peculiarities of Chinese engagement and investments is that Africans feel heard by the Chinese when they present their development aspirations and financing needs.

An integration of the remits of FOCAC, BRI, and Agenda 2063 backed by proactive policymaking from the African side can achieve a lot. In addition, strategic Chinese investments could enhance technology and knowledge gains to help Africa develop requisite infrastructure development for effective CFTA and integration into the global value chain. The objective of the CFTA to create a continental market requires improved African infrastructure to facilitate transportation of goods and services across borders. This can be achieved by developing better regional or sub-regional coordination of priority projects while proactively improving Africans' negotiation skills to benefit more from Chinese engagement.

Finally, the burgeoning Africa-China relations pose an important question: When can we conclude that, indeed, the relationship has significantly contributed to achieving Africa's development goals? It is, perhaps, still too early to give a definitive answer. So, the best answer, as of now, is probably, "wait and see!" With cautious optimism, however, we can suggest that more proactive, forward-looking strategic policymaking from the African side has the potential to enhance Sino-African development possibilities for both sides.

\section{References}

Ado, A. \& Su, Z. 2016. China in Africa: A critical literature review. Critical Perspectives on International Business, 12(1): 40-60.

Ado, A., Su, Z., \& Wanjiru, R. 2017. Learning and knowledge transfer in Africa-China JVs: Interplay between informalities, culture, and social capital. Journal of International Management, 23(2): $166-179$.
African Union. 2018. About Agenda 2063. https://au.int/agenda2063/ about. Accessed on 19/09/2018.

Carmody, P., \& Kragelund, P. 2016. Who is in charge? State power and agency in Sino-African relations. Cornell International Law Journal, 49(1): 1-23.

Elu, J., \& Price, G. 2010. Does China transfer productivity enhancing technology to Sub-Saharan Africa? Evidence from manufacturing firms. African Development Review, 22(SI): 587-598.

Kaplinsky, R., \& Morris, M. 2009. Chinese FDI in sub-Saharan Africa: Engaging with large dragons. European Journal of Development Research, 21 (4): 551-569.

Kodzi, E. 2018. Live and let live: Africa's Response Options to China's BRI. In W. Zhang, I. Alon, \& C. Latteman (Eds), China's Belt and Road Initiative: 155-178. London: Palgrave Macmillan.

Lumumba-Kasongo, T. 2011 . China-Africa relations: A neo-imperialism or a neo-colonialism? A reflection. African and Asian Studies, 10(2-3): 234-266.

Mohan, G., \& Lampert, B. 2013. Negotiating China: Reinserting African agency into China-Africa relations. African Affairs, 112(446): 92-110.

Osabutey, E. L. C., Williams, K., \& Debrah, A. Y. 2014. The potential for technology and knowledge transfers between foreign and local firms: A study of the construction industry in Ghana. Journal of World Business, 49(4): 560-571.

Tugendhat, H., \& Alemu, D. 2016. Chinese agricultural training courses for African officials: Between power and partnerships. World Development, 81: 71-81.

Xinhua. 2018. Full text of Chinese President Xi Jinping's Speech at Opening Ceremony of 2018 FOCAC Beijing Summit. www.xinhuanet.com/english/2018-09/03/c_129946189.htm. Accessed 15/09/2018.

Xu, X., Li, X., Qi, G., Tang, L., \& Mukwereza, L. 2016 . Science, technology, and the politics of knowledge: The case of China's agricultural technology demonstration centers in Africa. World Development, 81: 82-91.

Zhao, S. 2014. A neo-colonialist predator or development partner? China's engagement and rebalance in Africa. Journal of Contemporary China, 23(90): 1033-1052.

Abdoulkadre Ado (aado@uottawa.ca) is an Assistant Professor of International Business at Telfer School of Management, University of Ottawa. He obtained his PhD in Canada, his MBA in China, and his Bachelor in Africa. His research investigates China-Africa cooperation and joint-ventures within the dynamics of FDI, learning and knowledge transfer, and informalities. His work has allowed him to visit more than forty countries. He is Vanier CGS recipient.

Ellis L.C. Osabutey (Ellis.Osabutey@roehampton.ac.uk) is a Reader in International Business and Strategy at Roehampton Business School, University of Roehampton. His research interests include FDI and Technology Transfer; Innovation, Technology and development; Institutional influences on International HRM/D \& Marketing. Ellis has published articles in journals such as Journal of World Business, Journal of Business Research, International Journal of Contemporary Hospitality Management, Technological Forecasting and Social Change, etc. 